\title{
In vitro resistance pattern of urinary tract infections-causing bacteria to ampicillin and ciprofloxacin
}

\begin{abstract}
Background: Urinary tract infection (UTI) is caused by microorganism mainly bacteria; therefore, initial empirical therapy of UTI is antibiotic. Once, ampicillin has been used as empirical therapy for UTI; however, it is no longer used as empirical therapy because of its high number of resistance. Theoretically, the resistance is carried by plasmid which will be lost in bacteria population if it has never been used. The objective of this study is to find whether ampicillin has potency to be sensitive again with the same resistance pattern as ciprofloxacin as reference.
\end{abstract}

Methods: Method of this study is cross-sectional study with urine samples collection at primary healthcare centers in Jakarta which were tested its resistance pattern to both of antibiotics. Out of 317 pregnant women who did examination, as many as 27 samples have UTI.

Results: Result of this study showed that resistance number of UTI-causing bacteria to ampicillin and ciprofloxacin and are $60.7 \%$ and $8.0 \%$ respectively and this difference is significant based on chi-square test with a $\mathrm{p}$ value of $<0.001$.

Conclusion: Resistance of ampicillin is high so that still cannot be used again as therapy of UTI particularly against Gram-negative bacteria. Surprisingly for Gram-positive bacteria, ampicillin is still likely to be reused as a treatment for UTI, but still need to be investigated further with a larger number of samples.

Keywords: ampicillin, bacteria, ciprofloxacin, resistance pattern, urinary tract infection
Volume 10 Issue 5 - 2019

\author{
Yeva Rosana,' Matthew Billy, ${ }^{2}$ Dwiana \\ Ocviyanti ${ }^{3}$ \\ 'Department of Microbiology, Faculty of Medicine, Universitas \\ Indonesia-Cipto Mangunkusumo General Hospital, Indonesia \\ ${ }^{2}$ Faculty of Medicine, Universitas Indonesia, Indonesia \\ ${ }^{3}$ Department of Obstetrics and Gynecology, Faculty of Medicine, \\ Universitas Indonesia-Cipto Mangunkusumo General Hospital, \\ Indonesia
}

Correspondence: Yeva Rosana, Department of Microbiology, Faculty of Medicine, Universitas Indonesia-Cipto Mangunkusumo General Hospital, Jakarta, Indonesia, Jl. Pegangsaan Timur 16, Jakarta 10320, Indonesia, Tel (62-2I) 3160492, Emailyeva.rosana@ui.ac.id

Received: September 28, 2019 | Published: October 16, 2019
Abbreviations: UTI, urinary tract infection; IDSA, infectious diseases society of America; CLSI, clinical and laboratory standard institute; ARESC, antimicrobial resistance epidemiological survey on cystitis

\section{Introduction}

A urinary tract infections (UTIs) is an infection in any part of urinary system. Prevalence of UTIs varies with sex, age, and urinary tract abnormality. ${ }^{1}$ Based on data from the Kidney and Urology Foundation of America, ${ }^{2}$ as many as $20 \%$ of American women have experienced UTIs in their lifetime. In Indonesia, the prevalence of UTIs is quite high at $3.2 \%$ at the age of $40-60$ years and $20 \%$ at the age of over 65 years. ${ }^{3}$

Etiology of UTIs is an infection by microorganisms, particularly by bacteria. Different types of bacteria can infect the urinary tract, including Escherichia coli, Klebsiella pneumoniae, Pseudomonas aeruginosa, Proteus mirabilis, Streptococcus agalactiae, Staphylococcus saprophyticus, and Enterobacter sp. The most common bacterial cause of UTIs in almost all cases in the world and at all ages is Escherichia coli. ${ }^{4}$

Infectious Diseases Society of America (IDSA) guidelines for initial treatment of UTI that are available in Indonesia are betalactams, phosphomycin, fluoroquinolones, and trimethoprim- sulfamethoxazole. ${ }^{5}$ These antibiotics are commonly recommended before definitive treatment according to resistance pattern test. ${ }^{4,5}$ The majority problem to treat UTIs are now resistant to one or more antibiotics. The drug ampicillin, once a common treatment, has been largely abandoned because most UTIs are now resistant to it.

Ampicillin belongs to beta-lactam antibiotics, a penicillin derivative antibiotic that was once recommended for UTI therapy. Ampicillin has action of inhibiting the synthesis of bacterial cell walls. Ampicillin has relatively few side effects. The use of ampicillin is very extensive for Gram-negative and positive bacteria which causes high level of resistance. ${ }^{6}$ The international study of ARESC (Antimicrobial Resistance Epidemiological Survey on Cystitis) with 4264 female patients showed that the prevalence of bacteria-causing UTI against ampicillin was about $51.7 \% .^{7}$ Another study showed the resistance reached 55.0\%. ${ }^{8}$ In Indonesia, study in Pekanbaru showed that resistance of UTI-causing bacteria against ampicillin was $81.3 \%{ }^{9}$

Molecularly, the mechanism of antibiotic resistance of ampicillin is carried by the plasmid. These plasmids of resistance will be lost in the bacterial population if they have not been used for years. ${ }^{7}$ Since ampicillin is not used for long periods of time to treat UTIs, ampicillin has the possibility of returning to become sensitive. If ampicillin sensitivity is proved again, there are various advantages obtained which are relatively low prices, few side effects, and can be reused as one of the antibiotic options for UTIs therapy. Ciprofloxacin is 
used a standard reference due to its low resistance, about $8.3 \%$ based on study. ${ }^{7}$ Ciprofloxacin is a quinolone antibiotic, although more susceptible than ampicillin, but it has some side effects particularly not safe for pregnant women, baby, and children. Therefore, it is necessary to examine further the reuse of ampicillin for UTIs

\section{Materials and methods}

\section{Specimen's collection}

The target population of this research was pregnant women who checked their pregnancy at primary health care centers in Jakarta. The sample of this research was patients who met the inclusion and exclusion criteria of the study. The inclusion criteria were:

a. Pregnant women who have their pregnancy examined

b. Patients who are willing to participate in this study and agree on the research informed consent.

Meanwhile, the exclusion criteria were pregnant women who take antibiotics for the last two weeks.

Urine specimens of these pregnant women were collected at several primary health care centers in Jakarta which are Pasar Rebo, Duren Sawit, Kramat Jati, Makasar, Pulo Gadung, and Cakung during 2015 to 2016. The urine specimen taken on this research is mid-stream urine. Then, the mid-stream urine specimen is cultured at Clinical Microbiology Laboratory, Faculty of Medicine - Cipto Mangunkusumo Hospital within a maximum of two hours. In case of delay in the process of delivery, the specimen may be stored at a temperature of $2-8^{\circ} \mathrm{C}$ for a maximum of 24 hours. ${ }^{10}$

\section{Culture and susceptibility testing}

Culture of the urine specimens used MacConkey and blood agar medium. Agar medium was incubated at $35-37^{\circ} \mathrm{C}$ for $18-24$ hours. Since inclusion criteria of this study were pregnant women with no clinical symptoms, the number of colonies should exceed $10^{5} \mathrm{CFU} /$ $\mathrm{mL} .{ }^{10}$ Identification and susceptibility testing used Vitek ${ }^{\circledR}$ Biomérieux using standard Clinical and Laboratory Standard Institute (CLSI). Sufficient number of pure isolates was suspended into $3 \mathrm{~mL}$ sterile saline (aqueous $0.45 \%$ to $0.50 \% \mathrm{NaCl}, \mathrm{pH} 4.5$ to 7.0 ) in a clear plastic (polystyrene) test tube $(12 \mathrm{~mm} \times 75 \mathrm{~mm})$. Homogenous organism suspension were prepared a with a density equivalent to a McFarland 0.5 using a calibrated VITEK ${ }^{\circledR} 2$ DensiCHEK ${ }^{\mathrm{TM}}$. Suspension tube and card were placed in the cassette. The card was incubated and the results were interpreted as final identification.

Bacterial sample was categorized as resistant to ampicillin if it had a minimum inhibitory concentration (MIC) $\geq 32 \mu \mathrm{g} / \mathrm{mL}$ according to CLSI International standard. Meanwhile, sample was categorized as resistant to ciprofloxacin if it had $\mathrm{MIC} \geq 4 \mu \mathrm{g} / \mathrm{mL} .^{11}$

Independent variable of this study was type of antibiotic which are ampicillin and ciprofloxacin. Dependent variable was bacterial resistance. Meanwhile, the confounding variable was sample handling and contamination.

\section{Data analysis}

Data processing and analysis was done using software "SPSS for Windows version 20.0". The data that has been inserted and processed will be analyzed by chi-square statistical test with significance value of 0.05 .

\section{Results}

\section{Study population}

In this study, out of 317 pregnant women who did examination at several primary health care centers in Jakarta, 27 samples were positive for UTI as depicted in Figure 1. Out of 27 urine samples, two samples were found consisting of two types of bacteria (multiple infection), so there were 29 types of bacteria that were tested for antibiotic resistance.

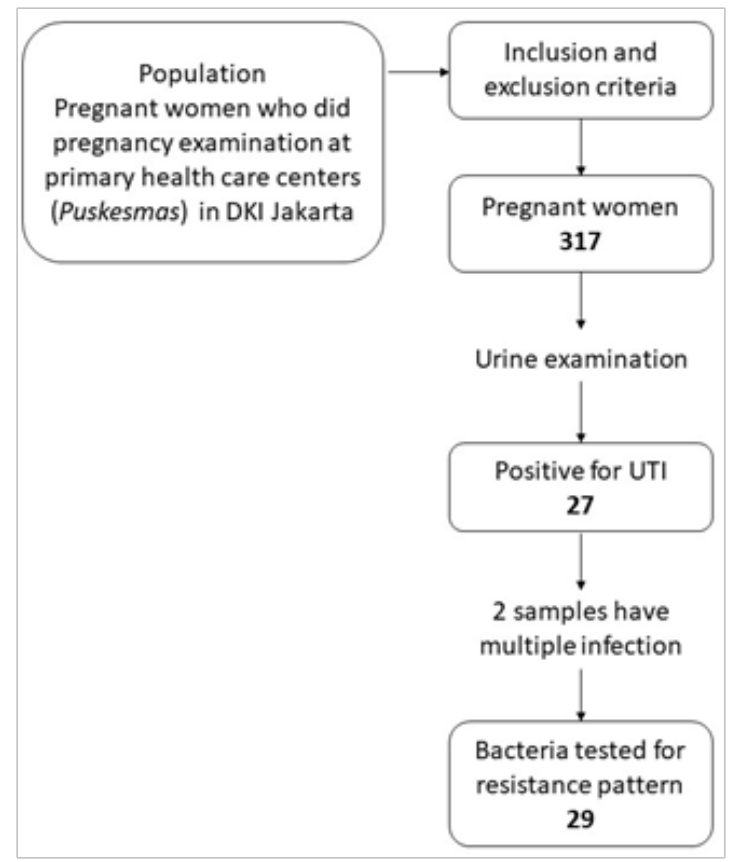

Figure I Subjects of this study.

\section{Resistance of UTI-causing bacteria to ampicillin and ciprofloxacin}

In this study, not all bacterial samples were tested against ampicillin. There are four samples that were not tested with ampicillin according to the antibiotic panel found on Vitek ${ }^{\circledR}$ Biomérieux cards with ST01 and GP67 codes. However, three of the four samples were tested with amoxicillin which was representative of ampicillin. ${ }^{10}$ So that, the number of bacterial samples tested against ampicillin were 28 samples.

According to CLSI International standard, 17 of $28(60.7 \%)$ bacterial samples in this study were resistant to ampicillin depicted in Table 1. For Gram-negative bacteria, 17 of 23 (73.9\%) bacterial sample were resistant to ampicillin. All Klebsiella pneumoniae sample as the most common Gram-negative bacteria in this study, were resistant. Meanwhile, Escherichia coli as the second most common Gram-negative bacteria showed that 3 of 7 samples $(2.9 \%)$ were resistant. Meanwhile, for all Gram-positive bacteria found in this study, no bacteria were resistant to ampicillin.

In this study, four samples consisting of three Streptococcus and one Leuconostoc bacteria were tested against ciprofloxacin according to the antibiotic panel on Vitek ${ }^{\circledR}$ Biomérieux card with ST01 code. Based on CLSI International standard ${ }^{12}$ ciprofloxacin is not indicated for UTI therapy caused by Streptococcus and Leuconostoc. In this 
study, 2 of $25(1.8 \%)$ bacterial samples were resistant to ciprofloxacin depicted in Table 2. For Gram-negative bacteria, 1 of $22(4.6 \%)$ bacterial sample was resistant to ciprofloxacin. Klebsiella pneumoniae as the most common Gram-negative bacteria in this study, showed no resistance against ciprofloxacin. Meanwhile, Escherichia coli as the second most common Gram-negative bacteria showed that 1 of 6 samples $(16.7 \%)$ were resistant. For Gram-positive bacteria, ciprofloxacin was tested on two samples which are Staphylococcus haemolyticus and Staphylococcus aureus. One of these two samples $(50 \%)$ was resistant.

Table I Resistance of UTI-causing bacteria to ampicillin

\begin{tabular}{lll}
\hline \multirow{2}{*}{ Bacteria } & \multicolumn{2}{c}{ Resistance } \\
\cline { 2 - 3 } Gram-positive bacteria & Nes \\
Leuconostoc mesenteroides & $\mathrm{I}$ \\
Streptococcus agalactiae & $\mathrm{I}$ \\
Staphylococcus haemolyticus & $\mathrm{I}$ \\
Streptococcus sanguinis & $\mathrm{I}$ & \\
Staphylococcus aureus & & \\
Streptococcus viridans & $\mathrm{I}$ & \\
Gram-negative bacteria & & \\
Stenotrophomonas maltophia & & $\mathrm{I}$ \\
Escherichia coli & 4 & 3 \\
Klebsiella pneumoniae & & 10 \\
Alicaligenes faecalis & $\mathrm{I}$ & \\
Pseudomonas stutzeri & $\mathrm{I}$ & \\
Acinetobacter baumannii & & 2 \\
Enterobacter cloacae & & $\mathrm{I}$ \\
Total & $\mathrm{II}$ & 17 \\
\hline
\end{tabular}

Table 2 Resistance of UTI-causing bacteria to ciprofloxacin

\begin{tabular}{|c|c|c|}
\hline \multirow{2}{*}{ Bacteria } & \multirow{2}{*}{$\begin{array}{l}\text { Resistance } \\
\text { No }\end{array}$} & \multirow[b]{2}{*}{ Yes } \\
\hline & & \\
\hline \multicolumn{3}{|l|}{ Gram-positive bacteria } \\
\hline \multicolumn{3}{|l|}{ Leuconostoc mesenteroides } \\
\hline \multicolumn{3}{|l|}{ Streptococcus agalactiae } \\
\hline Staphylococcus haemolyticus & & 1 \\
\hline \multicolumn{3}{|l|}{ Streptococcus sanguinis } \\
\hline Staphylococcus aureus & 1 & \\
\hline \multicolumn{3}{|l|}{ Streptococcus viridans } \\
\hline \multicolumn{3}{|l|}{ Gram-negative bacteria } \\
\hline Stenotrophomonas maltophia & 1 & \\
\hline Escherichia coli & 6 & 1 \\
\hline Klebsiella pneumoniae & 10 & \\
\hline Alicaligenes faecalis & 1 & \\
\hline Pseudomonas stutzeri & 1 & \\
\hline Acinetobacter baumannii & 2 & \\
\hline Enterobacter cloacae & 1 & \\
\hline Total & 23 & 2 \\
\hline
\end{tabular}

\section{Comparison of resistance pattern between ampicillin and ciprofloxacin}

Comparison of bacterial resistance pattern to ampicillin and ciprofloxacin was analyzed using Chi-square statistical test, which can be seen in Table 3. The resistance of samples to ampicillin was significantly higher than ciprofloxacin statistically.

Table 3 Comparison of resistance pattern between ampicillin and ciprofloxacin

\begin{tabular}{llll}
\hline \multirow{2}{*}{ Antibiotic } & \multicolumn{2}{l}{ Resistance } & \\
\cline { 2 - 3 } & No & Yes & \\
\hline Ampicillin & II $(39.3)$ & $17(60.7)$ & \\
Ciprofloxacin & $23(92.0)$ & $2(8.0)$ & $<0.00$ I \\
Total & $33(63.5)$ & $19(36.5)$ & \\
\hline
\end{tabular}

Comparison of resistance pattern for Gram-negative and positive bacteria can be seen in Table 4 and Table 5 . The resistance pattern of Gram-negative bacteria samples against both antibiotics was statistically significant with a $p$ value of $<0.001$. For Gram-positive bacteria, there was no bacteria resistance to ampicillin. Nevertheless, statistical test showed no significant difference between those two antibiotics for Gram-positive bacteria.

Table 4 Comparison of resistance pattern between ampicillin and ciprofloxacin for Gram-negative bacteria

\begin{tabular}{llll}
\hline \multirow{2}{*}{ Antibiotic } & \multicolumn{2}{l}{ Resistance } & \\
\cline { 2 - 3 } & No & Yes & p value \\
\hline Ampicillin & $6(26.1)$ & $17(73.9)$ & \\
Ciprofloxacin & $22(95.7)$ & $1(4.3)$ & $<0.00 \mathrm{I}$ \\
Total & $28(60.9)$ & $18(39.1)$ & \\
\hline
\end{tabular}

Table 5 Comparison of resistance pattern between ampicillin and ciprofloxacin for Gram-positive bacteria

\begin{tabular}{llll}
\hline \multirow{2}{*}{ Antibiotic } & \multicolumn{2}{l}{ Resistance } & p value \\
\cline { 2 - 3 } & No & Yes & \\
\hline Ampicillin & $5(100.0)$ & $0(0.0)$ & \\
Ciprofloxacin & $\mathrm{I}(50.0)$ & $\mathrm{I}(50.0)$ & 0.286 \\
Total & $6(85.7)$ & $\mathrm{I}(14.3)$ & \\
\hline
\end{tabular}

\section{Discussion}

In this study, UTI was diagnosed for 27 out of 317 samples (8.5\%) based on UTI diagnostic criteria. This result was consistent with several studies reporting that UTI was found $5-10 \%$ in pregnant women. ${ }^{13,14}$ In addition, the result was also consistent with previous study which estimated UTI covered $7.3 \%$ of pregnant women population. ${ }^{15}$

The main cause of UTI in this study was Gram-negative bacteria which covered $79.3 \%$. This is in accordance with various studies showed that the most common bacteria that cause UTI are Gramnegative bacteria, mainly originated from gastrointestinal tract. ${ }^{7,16,17}$ If female do not keep the vulva area clean, gastrointestinal flora may attach to the urinary tract epithelium and conduct ascending infection. 


\section{Resistance of UTI-causing bacteria to ampicillin}

Out of the 28 bacterial samples tested against ampicillin in this study, as many as $60.7 \%$ were found to be resistant. The resistance of ampicillin is in accordance with the various studies. The international study of ARESC (Antimicrobial Resistance Epidemiological Survey on Cystitis), which conducted a survey of 4264 female patients with uncomplicated UTI in Brazil and countries in Europe showed that the prevalence of bacteria-causing UTI against ampicillin was about $51.7 \%{ }^{7}$ The study also found that the highest resistance was ampicillin among other antibiotics. Another study showed similar results, the resistance of UTI-causing bacteria to ampicillin in female patients with uncomplicated UTI reached $55.0 \% .{ }^{8}$ In addition, studies in Iraq showed that bacterial UTI resistance against ampicillin reached $66.5 \%{ }^{9}$

In Indonesia, study in Pekanbaru showed that resistance of UTIcausing bacteria against ampicillin was $81.3 \% .^{18}$ That result showed that the resistance was slightly higher than this study. This may be due to differences in the subject of the study. In that study, the subjects of the study were patients with symptomatic UTI, so it was possible that the patient had been exposed to antibiotics before the urine sample was taken.

In this study, resistance of Klebsiella pneumoniae and Escherichia coli, as the most and second most common bacteria, against ampicillin reached $100.0 \%$ and $42.9 \%$. This was not much different from study that obtained $100 \%$ and $57.1 \%$ as the resistance of Klebsiella pneumonia and Escherichia coli against ampicillin. ${ }^{18}$

Thus, the number of ampicillin resistance was still high in Gramnegative bacteria. The high resistance of ampicillin is the reason why ampicillin is rarely used for infections, including UTI, which is mainly caused by Gram-negative bacteria. This resistance is mainly carried by plasmid pBR322. Obviously, with genes carried through plasmids, the transfer between bacteria becomes easier and thus increases the resistance rate. ${ }^{19}$ It takes time for the disappearance of the plasmid through natural selection for a long time, up to years. Resistance against ampicillin still existed in the population found in this study. This was possible because ampicillin was still used to treat some infections in Indonesia.

Surprisingly, for the five Gram-positive bacteria tested in this study, no bacteria were resistant to ampicillin. This result showed that ampicillin is still possible to be reused as a UTI therapy caused by Gram-positive bacteria.

\section{Resistance of UTI-causing bacteria to ciprofloxacin}

The resistance of bacterial sample against ciprofloxacin in this study was $8.0 \%$. The resistance is in accordance with recent various studies. Based on International study of ARESC (Antimicrobial Resistance Epidemiological Survey on Cystitis), which surveyed 4264 female patients with uncomplicated UTI in Brazil and countries in Europe, resistance against ciprofloxacin reached 8.3\%.7 Another study showed similar result, the resistance of UTI-causing bacteria against ciprofloxacin was about $8.8 \% .^{8}$ In addition, study in Iraq showed slightly higher results, the resistance reached $19.3 \%{ }^{9}$

In Indonesia, study in Pekanbaru showed the resistance of UTIcausing bacteria against ciprofloxacin was $70,6 \% .{ }^{18}$ Resistance of Klebsiella pneumoniae, as the most common Gram-negative bacteria, showed no resistance against ciprofloxacin. Study in Pekanbaru showed the different result. Klebsiella pneumoniae resistance was $80 \%$ against ciprofloxacin. ${ }^{18}$ That result was so different from this study. This may be due to difference in the subject of the study. Subjects of the study were patients with symptomatic UTI, so it was possible that the patient had been exposed to antibiotics before the urine sample was taken.

Data from Dr. Saiful Anwar Hospital in Malang also showed different result which $89.9 \%$ UTI-causing bacteria were resistant to ciprofloxacin. ${ }^{20}$ In that study, the subjects were inpatients. In hospital-acquired infections, bacteria are commonly resistant to broad spectrum of antibiotics. This was supported by study who found out that the resistance of UTI-causing bacteria was significantly higher in inpatients than outpatients. ${ }^{21}$

In this study, Escherichia coli resistance to ciprofloxacin was $16.7 \%$. This result differs from study at Fatmawati Hospital. The resistance of Escherichia coli resistance to ciprofloxacin was $84.6 \%$. This is accepted due to different in study subjects. In that study, the subjects were inpatients. ${ }^{15}$

\section{Comparison of resistance pattern between ampicillin and ciprofloxacin}

The resistance of uropathogen isolate to ampicillin was significantly higher than ciprofloxacin statistically. This result is in accordance with an ARESC international study with 4264 female patients with uncomplicated UTI in Brazil and countries in Europe. ${ }^{7}$ Similar results were also found in study in Pekanbaru, Indonesia. ${ }^{18}$

Comparison of resistance pattern for Gram-negative bacteria to ampicillin and ciprofloxacin was analyzed using Chi-square test. Ampicillin has a higher resistance pattern than ciprofloxacin with for Gram-negative bacteria. This result is in accordance with the study in Pekanbaru, Indonesia. ${ }^{18}$ Therefore, resistance of ampicillin is high so that still cannot be used again as therapy of UTI particularly against Gram-negative bacteria. Surprisingly for Gram-positive bacteria, no bacteria were resistant to ampicillin.

There are limitations of this study. First, the sample was not analyzed in vivo. This is because ampicillin is no longer used to treat UTI as single regiment, but in combination with sulbactam. Second, the sample size for Gram-positive bacteria was too small. Although there is some limitation in this study, but it can be reported that ampicillin is still likely to be reused as a treatment for UTIs particularly for Gram positive bacteria as the common etiology of UTIs in pregnant women. Investigation further still needs to be conducted with a larger number of samples.

\section{Acknowledgments}

This study was funded by Zambon Indonesia. Authors give acknowledgement to our colleagues, Friza Y Harlinda, Melissa Halim, Rahmah Amran, Wafridha Akbar, Syadza RP Akhmad, and senior's co-ass from Faculty of Medicine, Universitas Indonesia, Jakarta for collaborative cooperation in samples collection. Deep appreciation to team from Department of Microbiology and Obstetrics Gynecology, Faculty of Medicine, Universitas Indonesia for technical assistance, as well as support for this article.

\section{Funding}

None. 


\section{Conflicts of interest}

The author affirms no conflict of interest in publication of this study.

\section{References}

1. Dielubanza EJ, Schaeffer AJ. Urinary tract infections in women. Med Clin North Am. 2011;95(1):27-41.

2. August SL, De Rosa MJ. Evaluation of the prevalence of urinary tract infection in rural Panamanian women. PLoS One. 2012;7(10):e47752.

3. Totsika M, Moriel DG, Idris A, et al. Uropathogenic Escherichia coli mediated urinary tract infection. Curr Drug Targets. 2012;13(11):13861399.

4. Rowe TA, Juthani-Mehta M. Diagnosis and management of urinary tract infection in older adults. Infect Dis Clin North Am. 2014;28(1):75-89.

5. Grabe M, Bjerklund-Johansen TE, Botto H, et al. Guidelines on urological infections. European Association of Urology; 2013.

6. Bennett PM. Plasmid encoded antibiotic resistance: acquisition and transfer of antibiotic resistance genes in bacteria. $\mathrm{Br} J$ Pharmacol. 2008;153 Suppl 1:S347-357.

7. Schito GC, Naber KG, Botto $\mathrm{H}$, et al. The ARESC study: An international survey on the antimicrobial resistance of pathogens involved in uncomplicated urinary tract infections. Int $J$ Antimicrob Agents. 2009;34(5):407.

8. Nickel JC. Urinary tract infections and resistant bacteria: Highlights of a symposium at the combined meeting of the 25 th International Congress of Chemotherapy (ICC) and the 17th European Congress of Clinical Microbiology and Infectious Diseases (ECCMID), March 31-April 3, 2007, Munich, Germany. Rev Urol. 2007;9(2):78-80.

9. Al-Jebouri MM, Mdish SA. Antibiotic resistance pattern of bacteria isolated from patients of urinary tract infections in Iraq. OJU. 2013;03(02):124-131.

10. Trautner BW, Grigoryan L. Approach to a positive urine culture in a patient without urinary symptoms. Infect Dis Clin North Am. 2014;28(1):15-31

11. Biomerieux. Vitek 2 instrument user manual. Durham: Biomerieux; 2008.

12. Semeniuk H, Church D. Evaluation of the leukocyte esterase and nitrite urine dipstick screening tests for detection of bacteriuria in women with suspected uncomplicated urinary tract infections. J Clin Microbiol. 1999;37(9):3051-3052.

13. McGarry KA, Tong IL. The 5-minute consult clinical companion to women's health. 2nd ed. Philadelphia: Lippincott Williams and Wilkins; 2013. 199 p.

14. Smaill FM, Vazquez JC. Antibiotics for asymptomatic bacteriuria in pregnancy. Cochrane Database Syst Rev. 2015;(8):CD000490.

15. Ocviyanti D, Fernando D. Management and prevention of urinary tract infections in pregnancy. J Indon Med Assoc. 2012;62(12):482-487.

16. Pratiwi DS. Study of resistance and sensitivity test of ceftriaxone and ciprofloxacin antibiotics in patients with urinary tract infections in Fatmawati General Hospital. UIN Syarif Hidayatullah Jakarta; 2013.

17. Patel AS, Saira R, Ameeta K. Assessing the management of urinary tract infections at a large, urban teaching hospital. Ann Infect Dis Epidemiol. 2017;2(2):1015.

18. Endriani R, Andrini F, Alfina D. Pattern of bacterial resistance that causes urinary tract infections (UTI) to antibacterial in Pekanbaru. Jurnal Natur Indonesia. 2010;12(2):130-135.

19. Balbás P, Bolívar F. Back to basics: pBR322 and protein expression systems in E. coli. Methods Mol Biol. 2004;267:77-90.

20. Subandiyah K. Pattern and sensitivity to bacterial antibiotics that cause pediatric urinary tract infections in Dr. Saiful Anwar General Hospital, Malang. Brawijaya Medical Journal. 2004;20(2):57-61.

21. Saperston KN, Shapiro DJ, Hersh AL, et al. A comparison of inpatient versus outpatient resistance patterns of pediatric urinary tract infection. J Urol. 2014;191(5 Suppl):1608-1613. 